\title{
Peran Ulama Perempuan dalam Menanggapi Perkawinan Anak di Indonesia
}

\author{
Paulus Eko Kristianto \\ Sekolah Tinggi Filsafat Driyarkara \\ Jakarta \\ email: paulusekokristianto@gmail.com
}

\begin{abstract}
In this article, the author tries to ask the question of the role of female scholars in responding to child marriage in Indonesia? The author tries to answer this question with the literature study method on various books and describes them in the sub-discussion of female scholars; a description of the situation of child marriage in the world and Indonesia; child marriage, law, and legal practice; and the role of female scholars in responding to child marriage. Through this step, the authors hope this article can contribute perspectives and alternatives to women scholars in responding to child marriage in Indonesia.
\end{abstract}

Keywords: role; female ulama; child marriage; Indonesia

\begin{abstract}
Abstrak: Dalam penulisan artikel ini, penulis mencoba mengajukan pertanyaan bagaimana peran ulama perempuan dalam menanggapi perkawinan anak di Indonesia? Penulis mencoba menjawab pertanyaan tersebut dengan metode studi pustaka terhadap berbagai buku-buku dan menguraikannya dalam sub bahasan ulama perempuan; gambaran situasi perkawinan anak di dunia dan Indonesia; perkawinan anak, hukum, dan praktik hukum; dan peran ulama perempuan dalam menanggapi perkawinan anak. Melalui langkah ini, penulis berharap artikel ini dapat memberi sumbangsih perspektif dan alternatif bagi ulama perempuan dalam menanggapi perkawinan anak di Indonesia.
\end{abstract}

Kata Kunci: peran; ulama perempuan; perkawinan anak; Indonesia

\section{A. Pendahuluan}

UNICEF menunjukkan bahwa perkawinan anak didefinisikan sebagai perkawinan formal atau informal sebelum usia 18 tahun. ${ }^{1}$ Perkawinan anak tersebar luas dan dapat menyebabkan kerugian dan kekurangan seumur hidup. Berdasarkan data UNICEF, di seluruh dunia, lebih dari 650 juta wanita yang

1UNICEF, "Harmful Practices," www.UNICEF.org, 2018, diakses pada 28 Agustus 2018, https://www.UNICEF.org/protection/harmful-practices. 
hidup hari ini menikah saat masih anak-anak. ${ }^{2}$ Diperkirakan 12 juta anak perempuan di bawah 18 tahun menikah setiap tahun. Perempuan yang menikah sebelum usia 18 tahun cenderung tidak bersekolah dan cenderung mengalami kekerasan dalam rumah tangga. Remaja perempuan muda sering meninggal karena komplikasi kehamilan dan persalinan daripada perempuan di usia 20an. Selain itu, bayi mereka cenderung lahir meninggal di bulan pertama kehidupan.

Berpijak pada kondisi tersebut, dalam konteks kajian ulama perempuan, penulis mengajukan pertanyaan bagaimana peran ulama perempuan dalam menanggapi perkawinan anak di Indonesia? Penulis mencoba menjawab pertanyaan tersebut dengan metode studi pustaka terhadap berbagai bukubuku dan menguraikannya dalam sub bahasan ulama perempuan; gambaran situasi perkawinan anak di dunia dan Indonesia; perkawinan anak, hukum, dan praktik hukum; dan peran ulama perempuan dalam menanggapi perkawinan anak. Melalui langkah ini, penulis berharap artikel ini dapat memberi sumbangsih perspektif dan alternatif bagi ulama perempuan dalam menanggapi perkawinan anak di Indonesia.

\section{B. Ulama Perempuan}

Kata "ulama" berasal dari bahasa Arab, bentuk jamak dari kata "alim" yang berarti seseorang yang memiliki ilmu pengetahuan yang luas. Pada dasarnya istilah "ulama" secara sederhana berarti orang yang mengetahui, atau orang yang memiliki ilmu. Ulama bisa mencakup "orang-orang yang ahli dalam ilmu agama dan ilmu ilmu umum". 3 Peran ulama perempuan sangat besar dalam sosial keagamaan yang sering berkaitan dengan dunia perempuan, di antaranya Majlis Taklim, peran mereka bahkan melebihi batas keagaamaan dan wilayah. Seperti Rahmah El-Yunusiyah sebagai pelopor pendidikan, Nyai Ahmad Dahlan sebagai penggerak perempuan, Zakiyah Daradjat sebagai pendidik dan pemikir, dan Sholihah A. Wahid Hasyim sebagai teladan kaum perempuan Nahdliyin.

\footnotetext{
2UNICEF.

3Jajat Burhanudin, ed., Ulama Perempuan Indonesia (Gramedia Pustaka Utama bekerja sama dengan PPIM IAIN Jakarta, 2002), xxviii.
} 
Lantas, apakah benar peran ulama perempuan di masyarakat dikategorikan minim? Uraian dalam Republika edisi Rabu, 12 November 2010 membenarkannya dengan menyatakan peran dan andil ulama perempuan kepada masyarakat selama ini belum maksimal. Hal ini dikarenakan banyak persoalan diskriminasi gender dan marginalisasi perempuan yang seharusnya dipecahkan ulama perempuan. ${ }^{4}$ Namun, hal ini sulit dilakukan sebab minimnya kontribusi ulama perempuan yang dipandang berkarisma dan berwibawa tinggi dari segi keilmuan, berdikari, dan kesahajaan. Selain itu, ulama perempuan dinilai masih terpaku pada referensi klasik yang cenderung membatasi peran aktif perempuan di masyarakat, contohnya dalam mazhab Syafii ditegaskan bahwa perempuan tak berhak menjadi pemimpin, baik dalam urusan syariat maupun negara.

Alternatif yang biasa dilakukan untuk memicu peran yang lebih besar ulama perempuan yaitu mempertemukan para ulama perempuan terkemuka. ${ }^{5}$ Melalui pertemuan tersebut, mereka diminta mengidentifikasikan masalah dan menyamakan persepsi dalam mempersiapkan kader yang sangat menguasai ilmu dan sifat arif. Bahkan, pemerintah sudah menerapkan kebijakan untuk meningkatkan peran aktif tokoh perempuan dalam berbagai sisi, salah satunya menyertakan mereka di ranah publik. Ulama perempuan juga dilibatkan secara aktif oleh pemerintah dalam pembinaan dan pelayanan umat. Setidaknya, tercatat sebanyak 23,489 \% perempuan penyuluh agama yang tersebar di seluruh Indonesia. ${ }^{6}$

\section{Perkawinan Anak di Dunia dan Indonesia}

Web Girls not bridges menunjukkan bahwa pengantin anak perempuan dapat ditemukan di setiap wilayah di dunia, dari Timur Tengah ke Amerika Latin, Asia Selatan ke Eropa. ${ }^{7}$ Data UNICEF menunjukkan persentase 20 negara

\footnotetext{
${ }^{4}$ Agung Sasongko, "Beginilah Gambaran Peran Ulama Perempuan," Republika Online - Rabu 24 Nov 2010, 2010, https://www.republika.co.id/berita/dunia-islam/islam-nusantara/10/11/24/ 148406-beginilah-gambaran-peran-ulama-perempuan.

${ }^{5}$ Sasongko.

${ }^{6}$ Sasongko.

7“Child Marriage around the World," Girls Not Brides, diakses 28 Agustus 2018, https://www.girlsnotbrides.org/where-does-it-happen.
} 
dengan tingkat perkawinan tertinggi yaitu (1) Niger dengan $76 \%$; (2) Republik Afrika Tengah dengan 68 \%; (3) Republik Chad dengan 67 \%; (4) Bangladesh dengan 59 \%; (5) Burkina Faso dengan 52 \%; (6) Mali dengan 52 \%; (7) Sudan Selatan dengan $52 \%$; (8) Guinea dengan $51 \%$; (9) Mozambique dengan $48 \%$; (10) Somalia dengan 45 \%; (11) Nigeria dengan $44 \%$; (12) Malawi dengan 42 \%; (13) Eritrea dengan $41 \%$; (14) Madagascar dengan $41 \%$; (15) Ethiopia dengan $40 \%$; (16) Nepal dengan $40 \%$; (17) Uganda dengan 40 \%; (18) Sierra Leone dengan $39 \%$; (19) Democratic Republic of the Congo dengan 37 \%; (20) Mauritania with $20 \%{ }^{8}$ Berdasarkan data UNICEF, ada 20 negara dengan jumlah perkawinan anak tertinggi yaitu (1) India dengan 15.509.000; (2) Bangladesh dengan 4.451.000; (3) Nigeria dengan 3.538.000; (4) Brazil dengan 3.034.000; (5) Ethiopia dengan 2.104.000; (6) Pakistan dengan 1.909.000; (7) Mexico dengan 1.479.000; (8) Indonesia dengan 1.459.000; (9) Democratic Republic of the Congo dengan 1.300.000; (10) Uganda dengan 787.000; (11) Tanzania dengan 779.000; (12) Filipina dengan 726.000; (13) Mesir dengan 683.000; (14) Niger dengan 676.000; (15) Mozambique dengan 649.000; (16) Sudan dengan 640.000; (17) Nepal dengan 587.000; (18) Afghanistan dengan 572.000; (19) Thailand dengan 543.000; dan (20) Kenya dengan 527.000.

Perkawinan anak di Indonesia cenderung terjadi di daerah pedesaan. Misalnya, Sulawesi Barat mengalami tingkat perkawinan anak tertinggi sebelum usia 15 tahun. $^{9}$ Hal itu dikarenakan praktik tersebut merupakan tradisi budaya yang tertanam kuat. Menurut UU Perkawinan tahun 1974, anak perempuan dapat menikah sejak usia 16 tahun, sedangkan anak laki-laki dapat menikah pada usia 19 dengan izin orang tua. Pada tahun 2014, gerakan akar rumput yang disebut Koalisi +18 berkampanye meningkatkan usia minimum perkawinan menjadi 18 tanpa kecuali. Namun, pada Juni 2015, Mahkamah Konstitusi memegang teguh hukum perkawinan Indonesia tahun 1974. Kasus ini memacu dialog nasional seputar perkawinan anak di negara. Kenapa hal itu terjadi? Ada rasa diam yang luar biasa di sekitar perkawinan anak. Masyarakat menerimanya sebagai bagian dari tatanan sosial. Mereka jarang berbicara tentang efek dan konsekuensinya.

8"Child Marriage around the World."

9"Child marriage around the world." 
Sebagian besar, praktek perkawinan anak di Indonesia didorong oleh faktor-faktor sosioekonomi yang melingkupi anak perempuan, termasuk kemiskinan, ketergantungan ekonomi, insentif keuangan dan praktik mahar, serta kurangnya akses ke pendidikan dan layanan kesehatan. Penelitian dari Plan International found menunjukkan bahwa salah satu pendorong utama perkawinan anak di Indonesia yaitu norma-norma gender yang kaku. ${ }^{10}$ Perkawinan anak dikaitkan dengan normalisasi kekerasan laki-laki terhadap perempuan dan anak perempuan karena perkawinan sering dipandang sebagai obat guna mengatasi stigma yang terkait dengan pengalaman seksual perempuan di luar pernikahan, termasuk dalam konteks pelecehan seksual. Konsekuensi negatif utama untuk anak perempuan yaitu berkurangnya kesempatan pendidikan, bahaya kesehatan reproduksi (pengiriman yang sulit dan risiko HIV/AIDS yang lebih tinggi, bayi prematur penyandang disabilitas), dan meningkatnya risiko kematian ibu dan anak ${ }^{11}$ Perkawinan anak juga merupakan sumber trauma psikologis serta kekerasan dalam rumah tangga dan seksual. Bahkan, hal itu mengarah pada eksploitasi pengantin anak sebagai pembantu rumah tangga atau sebagai korban perdagangan seks, baik di dalam pernikahan mereka atau setelahnya, ketika mereka ditinggalkan atau diceraikan.

Perkawinan anak mempengaruhi kesejahteraan anak secara keseluruhan, terutama kesejahteraan fisik dan psikologis mereka, serta status dan kekuasaan dalam rumah tangga. ${ }^{12}$ Perempuan dari $20 \%$ rumah tangga termiskin cenderung menikah sebelum 18 tahun, dibandingkan dengan perempuan dari $20 \%$ rumah tangga terkaya. Penerimaan praktek perkawinan tidak hanya berasal dari kemiskinan, meskipun keamanan finansial tidak menawarkan perlindungan total karena hampir satu dari enam anak perempuan dari keluarga kaya menikah sebelum usia 18 tahun. ${ }^{13}$ Di antara pengantin anak

\footnotetext{
10"Child marriage around the world."

${ }^{11}$ Mies Grijns dan Hoko Horii, "Child Marriage in a Village in West Java (Indonesia): Compromises between Legal Obligations and Religious Concerns," Asian Journal of Law and Society 5, no. 2 (2018): 453-66, https://doi.org/10.1017/als.2018.9.

12Joseph Natanael Marshan, Fajar Rakhmadi, dan Mayang Rizky, "Prevalence of Child Marriage and Its Determinants among Young Women in Indonesia," 2010.

13Marshan, Rakhmadi, dan Rizky.
} 
yang berusia 10-14 tahun pada tahun 2010, 74,5\% dikategorikan tidak miskin. Di antara perempuan berusia 15-19 tahun dan 20-24 tahun yang menikah pada usia di bawah 18 tahun, 82,5\% dan 83,7\% masing-masing juga terkategori tidak miskin. ${ }^{14}$ Banyak remaja perempuan yang menikah tidak menyelesaikan pendidikan di luar tingkat sekolah dasar, hampir sepertiga anak perempuan yang menikah melaporkan sekolah dasar sebagai tingkat pendidikan tertinggi mereka dibandingkan dengan anak perempuan yang tidak menikah (masingmasing 36\% dan 24\%). Sekolah menengah diharapkan dapat memberikan perlindungan terbaik untuk menunda pernikahan. ${ }^{15}$

Di Indonesia, dengan tidak adanya sumber daya ekonomi yang memadai untuk keamanan keuangan perempuan, banyak perempuan sering menggunakan strategi perkawinan yang disebut nikah siri (menikah hanya di depan seorang pemimpin agama), yang tidak diikat secara hukum oleh negara. Perkawinan itu hanya diberkati oleh ustad atau ulama (pemimpin agama). Dengan demikian, keluarga dengan ekonomi rendah akan menerima tawaran perkawinan dari keluarga lain, yang akan menawarkan mahar atau mas kawin tertentu. Padahal, hak menerima atau menolak mahar terletak pada mempelai perempuan, tetapi biasanya justru orang tua mereka yang menentukan. Dalam beberapa kasus, persetujuan tidak dianggap atau diminta. Hal ini diilustrasikan dengan contoh berikut. Banyak remaja perempuan dinikahkan ayahnya tanpa pemberitahuan sebelumnya sehingga remaja tersebut cenderung kaget sepulangnya dari sekolah.

\section{Perkawinan Anak, Hukum, dan Praktik Hukum}

Pada tahun 1973, pemerintah menyerahkan Rancangan Undang-undang (RUU) Perkawinan kepada Parlemen. Hal itu dilakukan dengan tujuan meningkatkan hak-hak perempuan dalam perkawinan. ${ }^{16}$ Namun beberapa organisasi Muslim dan partai Islamis (Partai Persatuan Pembangunan) sangat

\footnotetext{
${ }^{14}$ Marshan, Rakhmadi, dan Rizky.

${ }^{15}$ Marshan, Rakhmadi, dan Rizky.

${ }^{16}$ S. Pompe dan J. M. Otto, "Some Comments on Recent Developments in the Indonesian Marriage Law with Particular Respect to the Rights of Women," Verfassung und Recht in Übersee / Law and Politics in Africa, Asia and Latin America 23, no. 4 (1990): 415-33, https://doi.org/10.2307/43109991.
} 
menentang RUU tersebut dengan alasan bahwa hal itu terlalu modern. Mereka melakukan walk-out dari parlementer yang menyebabkan pemerintah menyimpulkan bahwa biaya proposal tersebut terlalu tinggi. Pemerintah memahami bahwa hukum diperlukan untuk mengakomodasi keragaman dalam praktik pernikahan dan gagasan normatif yang mendasari mereka. Akibatnya, pemerintah mengubah beberapa pasal dalam draf, termasuk pasal tentang usia menikah. Draf awal mengusulkan usia pernikahan minimum yaitu 18 tahun untuk perempuan dan 21 tahun untuk laki-laki. ${ }^{17}$ Setelah menghadapi oposisi yang kuat dari kelompok Muslim konservatif, pemerintah menurunkan usia menikah menjadi 16 untuk anak perempuan dan 19 untuk anak laki-laki.

Kajian hukum terhadap Undang-Undang Perkawinan tahun 1974 di Mahkamah Konstitusi, yang diajukan oleh organisasi perempuan dan pemuda, untuk menaikkan usia minimum menikah, telah ditolak. Selama audiensi, semua pendapat organisasi agama utama disajikan. Para hakim tampaknya mengabaikan pandangan para ahli Muslim dan non-Muslim moderat tentang konsekuensi negatif dari perkawinan anak untuk anak perempuan yang hanya mengacu pada standar Muslim mengenai kematangan mental dan fisik (akil baligh) sebagai ukuran pernikahan. Satu-satunya perbedaan pendapat di antara sembilan hakim yang mengacu pada hak asasi manusia dan pembangunan, berasal dari hakim perempuan satu-satunya, Maria Farida Indrati. Maria Farida Indrati menyatakan bahwa UU Perkawinan yang orisinil merupakan kompromi 41 tahun yang lalu, dan masyarakat Indonesia sejak saat itu telah mengembangkan pemahaman yang jauh lebih maju tentang hak asasi manusia dan pembangunan. ${ }^{18}$ Dia juga berpendapat bahwa berlanjutnya penggunaan usia 16 tahun untuk pernikahan anak perempuan justru menghasilkan ketidakpastian hukum dan undang-undang lain yang mengacu pada pemahaman usia 18 tahun sebagai akhir masa kanak-kanak. ${ }^{19}$ Meskipun Pasal 7 (1) UU Perkawinan membatasi usia 16 tahun untuk perempuan dan 19

\footnotetext{
17The Draft Marriage Law of 1973, Art. 7 (1), dikutip oleh Grijns dan Horii.

18Judgement No. 30-74/PUU-XII/2014

${ }^{19}$ GRIJNS dan HORII, “Child Marriage in a Village in West Java (Indonesia): Compromises between Legal Obligations and Religious Concerns."
} 
tahun untuk laki-laki, secara teknis siapapun dapat menikah di bawah usia tersebut jika pengadilan memberikan persetujuan. Hal itu dikarenakan Pasal 7 (2) memungkinkan orang tua dari pihak anak di bawah umur untuk mengajukan petisi dispensasi ke pengadilan. Undang-Undang tentang Hak Asasi Manusia tahun 1999 mendefinisikan anak-anak merupakan semua orang yang belum menikah di bawah usia 18, sedangkan anak yang sudah menikah, tanpa memandang usia mereka, berada di luar cakupan perlindungannya. Akibatnya, mereka kehilangan hak yang dijamin oleh UU Hak Asasi Manusia, di antaranya hak atas pendidikan, informasi, beristirahat, dan bergaul dengan anak-anak pada usia mereka sendiri.

Untuk mendaftarkan perkawinan dan perceraian, pasangan juga pergi ke kantor yang berbeda di kecamatan mereka seperti non-Muslim harus pergi ke Kantor Catatan Sipil dan Muslim ke Kantor Urusan Agama (selanjutnya ditulis KUA). Pengadilan agama dan sipil dapat mengesahkan perkawinan di bawah umur dengan memberikan dispensasi perkawinan. Ketika diberikan dispensasi, surat dari pengadilan memungkinkan para pemohon untuk mendaftarkan perkawinan mereka, termasuk pasangan yang menikah itu berada di bawah usia minimum standar perkawinan. Pasal 2 tentang Pendaftaran Perkawinan yang dikeluarkan oleh Departemen Agama menjelaskan bahwa pegawai KUA yang memeriksa persyaratan, serta memantau dan merekam perkawinan dan perceraian Muslim. Pasal 15 mengindikasikan bahwa jika persyaratan untuk perkawinan tidak dipenuhi, pendaftar perkawinan dilarang mendaftar. Pegawai KUA dilarang membantu pelaksanaan dan pendaftaran perkawinan jika persyaratan sebagaimana dimaksud dalam Pasal 5 (2) tidak dipenuhi dan mengetahui pelanggaran persyaratan atau ketentuan perkawinan. Undang-Undang Pencatatan Sipil No. 23 tahun 2006 lebih lanjut menetapkan berbagai hukuman untuk penipuan atau kegagalan untuk mendaftarkan perkawinan. Nurlaelawati menggambarkan KUA merupakan perantara antara ulama dan pengadilan agama. Hal ini dikarenakan pegawai KUA sering dianggap sebagai penjaga syariat dan interpretasi ulama, ketimbang pejabat negara. ${ }^{20}$ Lebih lanjut, Nurlaelawati juga

\footnotetext{
${ }^{20}$ Euis Nurlaelawati, Modernization tradition and identity: the Kompilasi Hukum Islam and legal practice in the Indonesian religious courts (Amsterdam: Amsterdam University Press, 2010),
} 
menekankan wawasan pejabat KUA berasal dari apa yang berakar kuat di masyarakat setempat. ${ }^{21}$ Selain pegawai KUA, para pemimpin lokal, seperti kepala desa dan amil, memainkan peran penting dalam mempersiapkan pendaftaran perkawinan. Amil merupakan asisten pencatat pernikahan di tingkat desa yang mendukung pendaftar perkawinan di tingkat kecamatan. Dalam prakteknya, mereka mendaftarkan perkawinan di KUA bekerjasama dengan para pencatat perkawinan sehingga orang-orang di desa hampir tidak perlu pergi ke KUA dan meninggalkan semua urusan. ${ }^{22}$

Mies Grijns dan Hoko Horii juga menemukan beberapa praktik ilegal perkawinan di bawah umur di Indonesia. ${ }^{23}$ Ketika orang-orang di desa membutuhkan solusi untuk situasi yang tidak diinginkan, mereka tidak pergi ke pengadilan untuk dispensasi perkawinan, tetapi beralih ke solusi lokal. Pengadilan dianggap mahal dan menakutkan (beberapa mengasosiasikan pengadilan dengan kasus pidana). Masyarakat lebih memilih cara yang paling aman, tercepat, dan terjangkau, yang berada di luar skema hukum negara. Perkawinan dimulai dengan upacara keagamaan. Ijab kabul menjadi inti bagi umat Islam. Hal ini dianggap langkah yang cukup untuk mengatasi masalah ketidakhormatan yang disebabkan oleh kehamilan yang tidak diinginkan atau kencan yang terlalu intim. Tetapi, tanpa registrasi, perkawinan semacam itu tidak sah menurut hukum negara. Hal ini juga berarti tidak ada akses bagi rumah tangga baru untuk mendapatkan dukungan kesejahteraan dari negara. Selain itu, anak-anak yang lahir dari pasangan tersebut hanya akan terdaftar atas nama ibu. Dalam masyarakat, hal ini dipandang membawa malu karena dianggap sebagai anak haram dan kehilangan hak waris. ${ }^{24}$

Mies Grijns dan Hoko Horii menunjukkan bahwa amil dan kepala desa (atau birokrat desa yang lebih rendah) adalah aktor utama. ${ }^{25}$ Mereka tidak

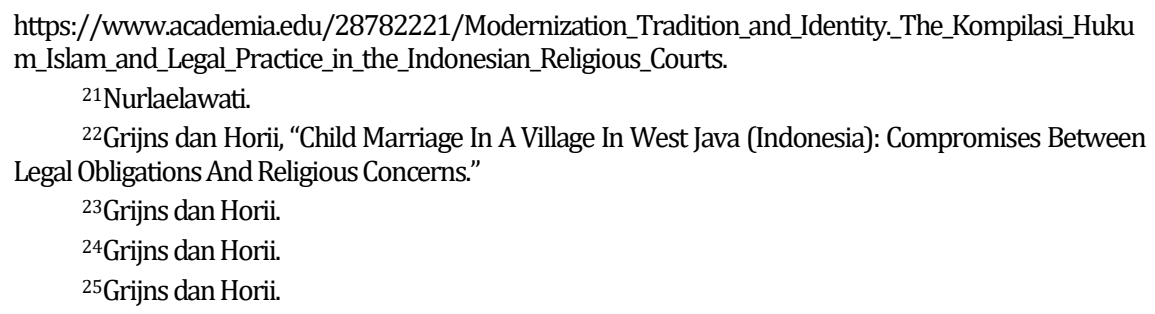


hanya mengatur perkawinan anak di bawah umur, tetapi mereka juga sering terlibat dalam mediasi perceraian yang secara teratur terjadi setelah perkawinan anak, membagikan surat cerai, mengatur akte kelahiran yang disesuaikan, dan merapikan kasus perzinahan. Amil dapat membantu orang menikah, termasuk ketika mereka datang kepadanya untuk meminta perkawinan pada hari berikutnya (bukannya menunggu sepuluh hari yang ditentukan secara hukum).26 Solusi kreatif untuk menghindari aturan prosedural tentang perkawinan di bawah umur telah menyebabkan rantai pelanggaran aturan lainnya. Dalam kasus perkosaan baru-baru ini, korban muda dipaksa oleh ayahnya untuk menikahi pemerkosanya untuk mencegah kehilangan kehormatan. ${ }^{27}$ Ia melewatkan ujian sekolah terakhirnya dan harus pindah dengan suaminya. Ketika ibunya, yang bekerja sebagai pembantu rumah tangga di Jakarta, mendengar tentang hal ini, ia memohon kepada para guru sekolah dan amil untuk mencari solusi lain. Pada akhirnya, pernikahan itu dibatalkan, gadis itu dinyatakan tidak pernah menikah dan diizinkan untuk mengikuti ujian akhir. Seakan tidak ada aturan resmi bahwa gadis-gadis yang menikah atau hamil tidak dapat melanjutkan pendidikan mereka, pernah menikah dengan atau tanpa bayi, bercerai atau tidak. ${ }^{28}$

\section{E. Peran Ulama Perempuan Menanggapi Perkawinan Anak}

Pemerintah Indonesia mengakui dampak dari perkawinan anak dan berupaya mendukung tujuan pembangunan berkelanjutan untuk periode 2015-2030. Mengakhiri perkawinan anak merupakan salah satu targetnya. Pemerintah Indonesia secara aktif terlibat dalam konvensi internasional, setelah meratifikasi Konvensi Penghapusan Segala Bentuk Diskriminasi terhadap Perempuan (Convention on the Elimination of All Forms of Discrimination against Women (CEDAW) pada tahun 1984 dan Konvensi HakHak Anak (Convention on the Rights of the Child (CRC)) pada tahun 1990. Presiden Joko Widodo baru-baru ini mendapat pujian atas strategi nasionalnya untuk menghapuskan kekerasan terhadap anak-anak, termasuk upaya inovasi

\footnotetext{
${ }^{26}$ Grijns dan Horii.

${ }^{27}$ Grijns dan Horii.

${ }^{28}$ Grijns dan Horii.
} 
untuk mengentaskan kemiskinan melalui skema perlindungan sosial. Kartu Indonesia Pintar (Smart Indonesia Card) mensubsidi peserta didik level sekolah dasar dan menengah dari latar belakang sosial ekonomi rendah, dan mendukung target kebijakan wajib belajar 12 tahun. Skema asuransi kesehatan nasional yang baru telah diperkenalkan untuk meningkatkan perawatan kesehatan bagi semua. Gagasan ini dipandang sebagai langkah penting guna mencegah perkawinan anak. Presiden Joko Widodo juga meminta Kementerian Pemberdayaan Perempuan dan Perlindungan Anak-anak untuk menyiapkan proposal untuk Peraturan Pemerintah sebagai Pengganti Undang-Undang (Perppu) tentang penghapusan perkawinan anak, yang disiapkan pada tahun 2016 bekerja sama dengan organisasi masyarakat sipil. ${ }^{29}$

Berbagai upaya yang sudah dilakukan pemerintah kiranya menginspirasi para ulama perempuan untuk terlibat aktif dalam menanggapi perkawinan anak di Indonesia. Lalu, bagaimana caranya? Bila dipetakan, ulama perempuan berperan sebagai:

\section{Pembimbing}

Oemar Hamalik menjelaskan pembimbing merupakan seseorang yang memberikan bantuan terhadap individu untuk mencapai pemahaman dan pengarahan diri yang dibutuhkan untuk melakukan penyesuaian diri secara maksimum terhadap sekolah, keluarga, maupun masyarakat. ${ }^{30}$ Proses ini diharapkan dilakukan tidak hanya melalui pendekatan instruksional, melainkan pendekatan personal pada setiap proses bimbingan. Oleh karenanya, ulama perempuan dalam konteks perkawinan anak diharapkan memberi bimbingan bagi masyarakat. Bimbingan tersebut dilakukan dalam rangka pencegahan dan penanggulangan terjadinya perkawinan anak.

\section{Pendidik}

Pendidik merupakan tenaga professional yang bertugas merencanakan dan melaksanakan proses pembelajaran, menilai hasil pembelaran, melakukan 2016), 17.

${ }^{29}$ Dian Kartikasari, Ke arah Perpu Anti Perkawinan Anak (Jakarta: Koalisi Perempuan Indonesia,

30Oemar Hamalik, Proses Belajar dan Mengajar (Jakarta: Bumi Aksara, 2004), 33. 
pembimbingan dan pelatihan, serta melakukan penelitian dan pengabdian masyarakat terutama bagi pendidik pada perguruan tinggi. ${ }^{31}$ Pendidik diharapkan memiliki atau menguasai ilmu-ilmu kependidikan, di antaranya pedagogi dan psikologi anak. Kompetensi pendidik demikian diharapkan memperlengkapinya ketika ulama perempuan mendidik santri dan masyarakat dalam rangka pencegahan dan penanggulangan terjadinya perkawinan anak.

\section{Penggerak Perempuan}

Penggerak perempuan dimaknai bahwa ulama perempuan diharapkan dapat menginspirasi dan menggerakkan perempuan lain dan masyarakat untuk memberikan terobosan tertentu bagi keadilan bersama, contohnya Nyai Dahlan, istri pendiri Muhammadiyah (organisasi Islam modern di Indonesia pada awal abad ke-20). Pada konteks perkawinan anak, ulama perempuan diharapkan dapat menggerakkan perempuan lain dan masyarakat untuk terlibat aktif mencegah dan menanggulangi perkawinan anak.

\section{Teladan}

Keteladanan dimaknai dengan upaya memberi contoh yang dilakukan tidak hanya melalui perkataan, melainkan perbuatan. Sebagai Ibu dari keenam putra-putrinya, Ibu Nyai Hj. Siti Asiyah menempatkan keteladanan yang baik bagi semua putra-putrinya. Beliau menyayangi semua anak-anaknya tanpa ada yang di anak emaskan. Beliau mengajarkan tauhid dengan berusaha melatih dan mengontrol anak-anaknya dalam melaksanakan sholat tepat waktu, belajar mengaji pada usia dini dan mengajarkan etika dan sopan santun. Pada konteks perkawinan anak, ulama perempuan diharapkan memberi keteladanan secara aktif mencegah dan menanggulangi perkawinan anak.

\section{F. Kesimpulan}

Setelah kita memperhatikan keseluruhan uraian dan berpijak pada pertanyaan panduan penulisan artikel ini, penulis menyimpulkan bahwa peran ulama perempuan dalam menanggapi perkawinan anak di Indonesia dapat dilakukan melalui tindakan sebagai pembimbing, pendidik, penggerak

31UU No. 20 Tahun 2003, Pasal 39 (2) 
perempuan, dan teladan. Tentu, proses ini dilakukan dengan memperhatikan konteks dan dinamika perkawinan anak di Indonesia.[s]

\section{Daftar Pustaka}

Burhanudin, Jajat, ed. Ulama Perempuan Indonesia. Gramedia Pustaka Utama bekerja sama dengan PPIM IAIN Jakarta, 2002.

"Child marriage around the world." Girls Not Brides. Diakses 28 Agustus 2018. https://www.girlsnotbrides.org/where-does-it-happen.

Grijns, Mies, dan Hoko Horii. “Child Marriage in a Village in West Java (Indonesia): Compromises between Legal Obligations and Religious Concerns." Asian Journal of Law and Society 5, no. 2 (2018): 453-66. https://doi.org/10.1017/als.2018.9.

Hamalik, Oemar. Proses Belajar dan Mengajar. Jakarta: Bumi Aksara, 2004.

Kartikasari, Dian. Ke arah Perpu Anti Perkawinan Anak. Jakarta: Koalisi Perempuan Indonesia, 2016.

Marshan, Joseph Natanael, Fajar Rakhmadi, dan Mayang Rizky. "Prevalence of Child Marriage and Its Determinants among Young Women in Indonesia," 2010.

Nurlaelawati, Euis. Modernization tradition and identity: the Kompilasi Hukum Islam and legal practice in the Indonesian religious courts. Amsterdam : Amsterdam University Press, 2010. https://www.academia.edu/28782221/Modernization_ Tradition_and_Identity._The_Kompilasi_Hukum_Islam_and_Legal_Practice_in_th e_Indonesian_Religious_Courts.

Pompe, S., dan J. M. Otto. "Some Comments on Recent Developments in the Indonesian Marriage Law with Particular Respect to the Rights of Women." Verfassung und Recht in Übersee / Law and Politics in Africa, Asia and Latin America 23, no. 4 (1990): 415-33. https://doi.org/10.2307/43109991.

Sasongko, Agung. "Beginilah Gambaran Peran Ulama Perempuan." Republika Online Rabu 24 Nov 2010, 2010. https://www.republika.co.id/berita/duniaislam/islam-nusantara/10/11/24/148406-beginilah-gambaran-peran-ulamaperempuan.

UNICEF. "Harmful Practices." www.unicef.org, 2018. https://www.unicef.org/ protection/harmful-practices. 
This page intentionally left blank 